\author{
(online) $=$ ISSN $2285-3642$ \\ ISSN-L $=2285-3642$ \\ Journal of Economic Development, Environment and People \\ Volume 8, Issue 4, 2019
}

URL: http://jedep.spiruharet.ro

e-mail: office_jedep@spiruharet.ro

\title{
How to lead with digital media effectively? A literature-based analysis of media in an E-leadership context
}

\author{
${ }^{1}$ Michael Hans Gino Kraft, Doctoral candidate \\ 2 Kaposvár University, Hungary
}

\begin{abstract}
In many companies and industries, the use of digital media is an essential prerequisite for leaders to communicate and collaborate with employees in spatially separated situations. From this point of view, leaders must use electronic media such as e-mail, telephone conferences and virtual platforms effectively for organizational purposes. Under this premise, this paper summarizes the arguments and counterarguments within the scientific discussion on the use of digital media in the context of E-leadership. The main purpose of the research is to uncover the different relevance of electronic media in the light of virtual team leadership. Therefore, this research represents a literature analysis of E-leadership media in virtual context. The review took place between April 2019 and June 2019. The paper provides first indications of the different relevance of electronic media for the leadership of virtual teams and identifies difficulties in the implementation and prioritization of electronic media. This analysis confirms and proves that, in addition to conceptual challenges in the area of E-leadership, the effective use of electronic media such as social media instruments can also be optimized by a better awareness of the use of media among leaders and employees.
\end{abstract}

Keywords: E-Leadership, digital media, digitalization, literature review, prioritization, social media, virtual teams

JEL Codes: M54, M19

How to cite: Kraft, M. (2019). How to lead with digital media effectively? A literature-based analysis of media in an Eleadership context.Journal of Economic Development, Environment and People, 8(4), 42-53. doi:http://dx.doi.org/10.26458/jedep.v8i4.639

\section{Introduction}

The increasing digitalization in companies over the last decades has changed almost every aspect of daily business. The effects of this development have created new opportunities to create flexible, agile and responsive structures that ensure the sustainable existence of the company in a competitive environment. However, the increasing implementation of digital elements in companies means that employees and leaders have to deal with digital media to be able to adapt to the circumstances and shape this digital change (Braun et. al., 2019). To embed technological elements in structures, processes and employees, the topic of ELeadership finds its relevance in a large number of scientific papers (Schoemaker et. al., 2018). In this context, E-Leadership uses new means of communication to overcome the obstacles of time and distance. An ELeader leads by information and communication technologies without personal interaction (Cascio \& Shurygailo, 2003). In addition to the challenge that today's leaders and employees have to face with digital 


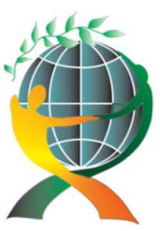

\author{
(online) $=$ ISSN $2285-3642$ \\ ISSN-L = $2285-3642$ \\ Journal of Economic Development, Environment and People \\ Volume 8, Issue 4, 2019 \\ URL: http://jedep.spiruharet.ro \\ e-mail: office jedep@spiruharet.ro
}

elements, a large number of current publications also emphasize the importance of virtual team elements for leadership behavior (McCann \& Sweet, 2014; Aviolo et. al., 2001; Hoch \& Kozlowski (2014).; Fan et. al. 2014; etc.). This argumentation is becoming increasingly important in leadership theory, since performance aspects relating to spatial separation are difficult to assess. In this context, assessments can become analyzed and understand through their use of digital system (Bossink, 2007). According to Manole (2014), in times of globalization, E-Leadership's technological opportunities can enable lower infrastructure costs through geographically dispersed teams while facilitating access to expertise for companies. In addition to the direct economic damage caused by the inefficient use of electronic media, this can also weaken the confidence of customers and employees (Vought, 2017).

Against this background, dealing with digital media is a challenging task, especially in virtual team situations. Leaders are needed who are able to effectively use technical instruments in order to anchor acceptance and performance in virtual teams (Zaccaro \& Bader, 2003). Because these teams consist of people of different nationalities, values, languages and age groups, this context should be given increasing importance. Although preliminary empirical results are promising, there are still many ways to fully understand the emergence and challenges of E-Leadership in leadership research (Avolio \& Kahai, 2003 ; Walumbwa et. al. 2004 ; DasGupta, 2011).

Given this evidence, the central question that motivates this paper is how important is E-leadership in leading virtual teams and which digital media are necessary to succeed in a digitalized environment? What is the attitude towards digital media by leaders? Which instruments would be used in terms of virtual leadership segments? To address these questions a literature-based review on instruments of the concept of E-Leadership in context of virtual team situations was conducted. This analysis does not yet exist. Only a relatively small part of the current articles like DasGupta (2011), Schmidt (2014) and Jiang et. al. (2016) focus on the use of digital media in a leadership context. However, these articles focused primarily on the impact of media usage on executives and employees. Additional work is highly warranted in terms of understanding the link between e-leadership and the effective use of digital media.

The results of the research are presented in the following logical sequence: After the relevance segment in the introduction, the basic theory and concept of e-Leadership in virtual teams is presented in a literature review. However, the main topic will be the extent to which E-leadership tools are already being used in virtual teams and what their priority is from a leadership perspective. Furthermore, in the context of digital media, the relevance of social media is analysed and challenges for leading virtual teams are discussed. In the final part, an overview of the limitations of this analysis will be presented. Further, as the digital age has not yet peaked, speculation regarding the future development of this topic will be briefly outlined.

\title{
2. Methodology
}

To answer the research question, a systematic literature analysis was conducted between April and June 2019 of scientific peer-review papers. In this context the EBSCO and Google Scholar databases were used to analyse this articles. The key words for finding articles and empirical works related to the research agenda are: "E-Leadership"; "Literature review of e-Leadership"; "digital-Leadership"; "virtual leadership" and In terms of digital media aspects: "digital media"; "electronic media" and "virtual media". This analysis of peerreviewed papers has meanwhile become of one commonly used method for assessing and exploring research gaps in leadership theory (Greenhalgh et. al. (2004).; DasGupta (2011); Sfantou et. al. (2017)). 


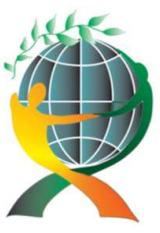

\author{
(online) $=$ ISSN $2285-3642$ \\ ISSN-L = $2285-3642$ \\ Journal of Economic Development, Environment and People \\ Volume 8, Issue 4, 2019 \\ URL: http://jedep.spiruharet.ro \\ e-mail: office jedep@spiruharet.ro
}

Therefore, this systematic literature review has been adapted using the following procedure described by DasGupta (2011) to examine the primary research questions on the relationship between the use of digital media and e-leadership. In this context, peer reviewed papers that explicitly mentioned the keywords in the abstracts or headlines were examined in the first step. The second step was to discuss the different results on the basis of the relevant articles.

\title{
3. E-Leadership in organizations
}

To fully explain the changes and development in leadership role and organizational structure, definitions of leadership and e-leadership will be mentioned and explained. The term leadership has been defined in numerous sources. However, the definitions are not notably different. After Day et. al. (2014), leadership means inspiring and influencing people, and the authors also emphasize the difference between management and leadership. A manager role is defined as involving organizing and planning. Nevertheless, to be a good leader, it is necessary for leaders to acquire the skills that would prepare them for possible changes and reorganization. These reorganization skills are said to be especially important in the digitalized companies. On the other hand, DuBrin (2015) defines leadership as a kind of ability to inspire and provide confidence and support among people who are needed to achieve organizational goals and purpose. More importantly, he explains that the term leadership could be an element of every organizational level, not reserved exclusively for the higher positions.

The role of leadership has been going through a series of changes in the past few decades, much like the rest of the business environment. These changes constitute the result of globalization and increased interconnectedness, and are an element of a VUCA (volatility, uncertainty, complexity and ambiguity) world. The VUCA environment has caused leadership forms to transform, whereby new skills and styles of team leadership have been realized. In a business context, this means adaptation to changes, as well as providing motivation for creativity and new ideas. This new set of skills should enable leaders to ensure the position of the organization in the market (Mironescu, 2013).

In order to adapt to changes and volatility, many organizations need to be as flexible and innovative as possible, which means skills such as agility and adaptability are of the utmost importance (Smith \& Cockburn, 2014). Moreover, it is not only necessary to be ready for change and structural innovation. Leaders' agility and adaptability should underpin their mindset, and they should be able to transfer that mindset to the rest of the organization's members. This changing mindset, however, is based on the technological development that enables workers to overcome time and space constraints and, therefore, also provides new means of communication and interaction in organizations. In the recently published work of Van Wart et al. (2019) it was also stated that digital competences are most important, especially in dealing with electronic media, so that teams can be able to work in a virtual context. In this context Paley (2017) explains the role of a modern leader not purely as a controller of a group, but also as a guide for implementing a team spirit and mutual vision, as well as a guide for creating a digital and connected environment. A leader plays a support role for both an individual and the team and works on creating cohesion between relationships among all members.

As a result of the VUCA environment and digital technology, a new model of leadership has appeared: eleadership. Avolio et al. (2014, p. 106) re-examine the role of leadership and probably have the most frequently mentioned definition of e-leadership. They define the term as "a social influence process embedded in both proximal and distal contexts mediated AITs [advanced information technologies] that 


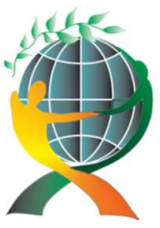

\author{
(online) $=$ ISSN $2285-3642$ \\ ISSN-L = $2285-3642$ \\ Journal of Economic Development, Environment and People \\ Volume 8, Issue 4, 2019 \\ URL: http://jedep.spiruharet.ro \\ e-mail: office jedep@spiruharet.ro
}

produce a change in attitudes, feelings, thinking, behavior, and performance." On the other hand, Roman et al. $(2018$, p. 10) agree with that definition, but also suggest their own. This new definition could be explained as an expansion of the Avolio et al definition "adding that the elements in the definition" are based on ability to communicate clearly and appropriately, provide adequate social interaction, inspire and manage change, build and hold teams accountable, demonstrate technological know-how related to ICTs, and develop a sense of trust in virtual environments." The new definition is closer to the present paper's research question, as it includes the aspects of social interaction and communication along with the interest in virtual teams. When analyzing the term of E-Leadership, it could be said that it does not differentiate significantly from the term of traditional leadership, except that it needs to be conducted digitally, cooperating with virtual teams, and overcoming the barriers of time and distance (DasGupta, 2011).

\title{
4. Virtual teams in organizations
}

According to van Wart et. al. (2016), the increase in digital elements has led to a significant change in leadership and organization, facilitating the development of virtual teams. These teams were at first meant to be a cost-saving measure because of how they eliminate the need for business infrastructure and employees around the world, instead making employees available anywhere at any time. However, the studies in the literature show that virtual teams have developed into something much bigger than simply a cost saving instrument. In order to the rise of Internet tools, they have developed from being merely a temporary solution for overcoming the obstacles of time and distance to a standard style of cooperation and communication (Alsharo et. al. 2017).

Manole (2014) also adds that, through virtual teams, organizations and businesses get a chance to acquire the best potential on the market regardless of their current geographical location. Moreover, the team members reach a level of flexibility and knowledge sharing that would not be possible in a traditional, face-to-face organization. She further explains the pitfalls of virtual communication-that is, how it can contribute to multicultural misunderstandings, among other problems such as difficulties requiring special training for certain team members (Hambley et. al., 2007).

Klus \& Müller (2018) describe virtual teams as groups with different backgrounds, diverse in age, knowledge and technology qualifications and, most importantly, without a regular face-to-face style of communication. Therefore, this environment is then as difficult to navigate, and requires new forms of communication and coordination. They also mention that different tools are used within virtual teams, many of which require specialized skills. These teams produce new challenges for leaders, meaning they must concentrate both on the needs of the team, generally, and of the individual who people the team.

In his review of the literature on E-Leadership, DasGupta (2011) explains how handling virtual teams is not merely a challenge of time and distance. According to DasGupta, virtual teams sometimes include members from other organizations, not necessarily only from their own departments. This combination of people from different backgrounds contributes to the complexity of leading such teams. In addition, they usually include multigenerational groups with different digital backgrounds and thus different adaptation requirements (Klus \& Müller, 2018). He further states the typical leadership role has significantly changed due to the rise of virtual teams. These days the primary responsibilities for leaders in digital environments is building trust inside a virtual team, using the ICT (Information and Communication Technology), managing the points of conflict within the team and avoiding or finding a solution for potential conflicts. 


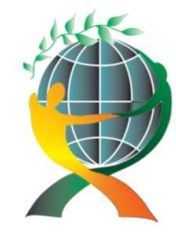

\author{
(online) $=$ ISSN $2285-3642$ \\ ISSN-L $=2285-3642$ \\ Journal of Economic Development, Environment and People \\ Volume 8, Issue 4, 2019 \\ URL: http://jedep.spiruharet.ro \\ e-mail: office_jedep@s,spiruharet.ro
}

Vought (2017) mentions six main characteristics of virtual teams: geographical separation of team members, digitalized means of communication without personal (face-to-face) interaction, individual work with a mutual goal or a purpose, team alterations, common responsibility of all team members for the result and cross-organizational relationship building.

Finally, team collaboration inside a virtual environment can be a challenge. Coordination and motivation of team members becomes the central task for the team leader. The leaders need to establish a system in which a team member would be able to stand out and gain recognition or some kind of reward for his or her performance and accomplishments. Another challenge is how to assign responsibility within a team and for a team as a whole in a virtual environment (Roman et al, 2018).

\title{
5. E-Instruments for leading virtual teams
}

In business organizations, digital technology can be used in two ways - internally and externally (Thomson et. al., 2018). Through means of mass communication (such as social networks and similar media platforms), the information of external participants is performed. The main characteristic of digital media is that it provides transparency but can also be used as a platform for generating new ideas and suggestions through stakeholder feedback. That said, for leadership roles it is more important that tools like social media can be used also for internal communication, for example between team members and other organization representatives. There are numerous ways of communicating within an organization (from the classical examples like email, phone, videoconference to more advanced ones such as document and knowledge exchange programs). Moreover, various software platforms, websites and interfaces are now used as a part of an internal feedback system aimed at achieving better communication and performance (Roman, et al., 2018). Although face-to-face communication is still the most popular way of communicating in a business environment, studies have shown that more than $75 \%$ of communication at work (other than face-to face) is now being conducted through email or telephone, depending on the type of assignment. Moreover, the use of proper communication tools is connected to managerial effectiveness (Braun et. al., 2019).

Liu et al. (2018) provide an explanation of a few specific ICT tools being used on a regular basis in ELeadership. They also stress the importance of social network awareness for effective leadership as an uninventable tool. Additionally, videoconferencing and document exchange platforms have been identified as tools with the largest amount of use in the past few years. Hertel et. al. (2017) claim that the use of communication tools depends on their richness and on the type of task at hand. This dependency is explained through "media richness theory," which states that simpler media is more appropriate for easier tasks, whereas more complex tasks require more advanced tools of communication. Furthermore, the intranet is also mentioned as a popular digital tool that allows for communication and leadership in digital environments. It is defined as an internal online network of an organization, which enables remote workers, or people working from home and places other than the organization's location to actively participate. The intranet has become an obligatory part of every large organization (Denton, 2006).

\section{Priority matrix for the use of digital media}

In a recent study from 2016, 126 managers of small and medium-sized enterprises were interviewed as part of a trend analysis with regard to digitalization projects (Mittelstand 4.0 Agentur Kommunikation, 2016). Surprisingly, there were deviations between the use of digital (communication) media and the assessment 


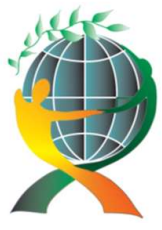

\author{
(online) $=$ ISSN $2285-3642$ \\ ISSN-L = $2285-3642$ \\ Journal of Economic Development, Environment and People \\ Volume 8, Issue 4, 2019
}

URL: http://jedep.spiruharet.ro

e-mail: office jedep@s,spiruharet.ro

of their significance. In this context, a priority matrix for digital media was developed in which the results of the study are presented. When comparing the use and importance of digital media in everyday working life, a number of striking differences were found.

From this it can be seen that the media used have different relevance from the point of view of managers. The most important media for managers in small and medium-sized enterprises, according to their own statements, are e-mails (94\%) and the intranet (71\%). This is followed by chats and messenger services (53\%) and in-house wiki (48\%). Social media only ranks fifth on the importance scale (42\%), followed by video conferencing (30\%) and blogs/micro-blogs (24\%). Consider the evaluation of frequency of media usage, it can be stated that the importance and frequency of use are congruent only for e-mail. Although in-house wiki and video conferencing seem to be extremely important to almost half of the respondents, they are rarely used in everyday working life. A similar picture emerges for blogs and micro-blogs: About a quarter of the respondents consider them important, but only 18 percent actually use them. This result suggests that leaders need support when using modern social (communication) media and that structured access should be established.

Priority matrix for digital media

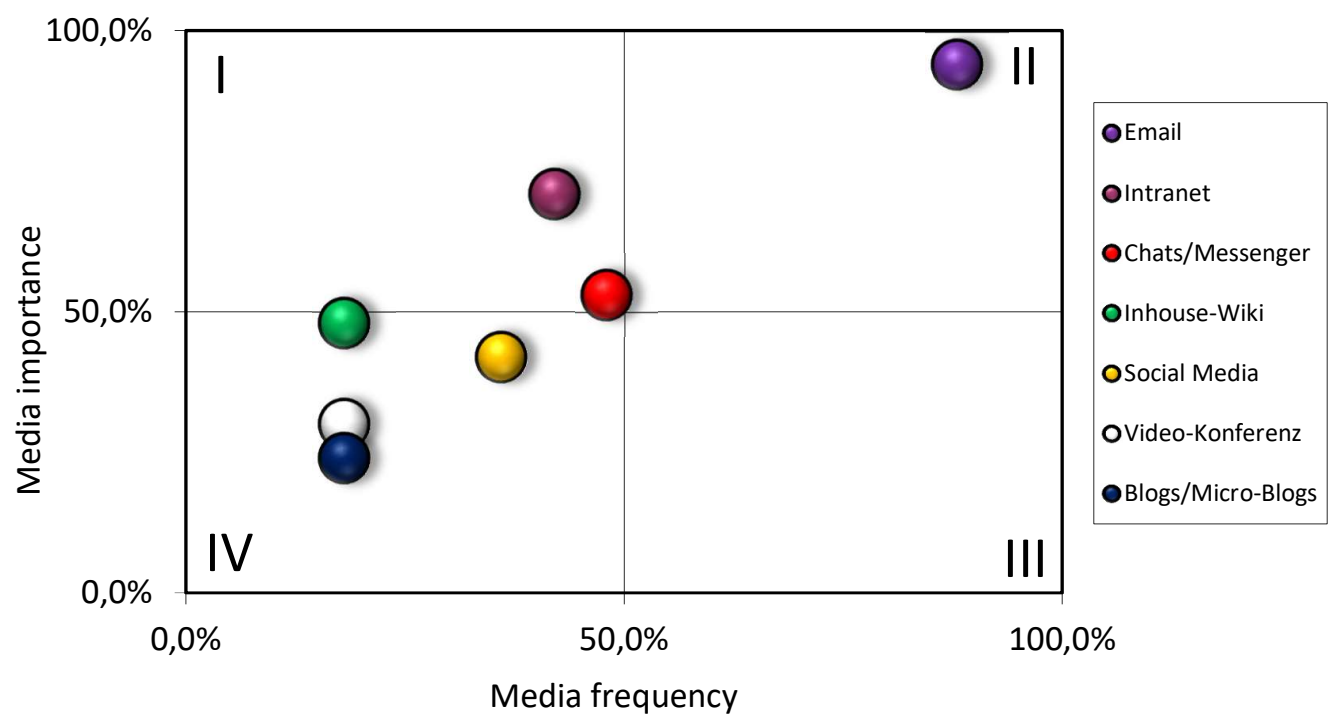

Fig. 1: Connection between media frequency and importance, own illustration

\title{
7. Social Networking
}

As already found out in the 2016 study, social media play an increasingly important role in the leadership context (Mittelstand 4.0 Agentur Kommunikation, 2016). According to Poell et. al. (2016), social media are frequently used by individuals and groups in both their private and business environments. The development of social networks arose simultaneously with the development of mobile devices. This combination led to increased mobile connectivity, which means that each individual is able to access their social networks and 


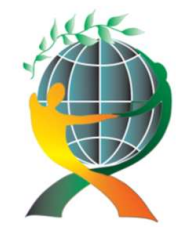

\author{
$($ online $)=$ ISSN $2285-3642$ \\ ISSN-L $=2285-3642$ \\ Journal of Economic Development, Environment and People \\ Volume 8, Issue 4, 2019
}

URL: http://jedep.spiruharet.ro

e-mail: office_jedep@s,spiruharet.ro

stay connected with the online community at any time and from anywhere. Given the level of interconnectedness and the speed of information exchange these advancements enable, social networks have been identified as one of the main instruments of E-leadership. They provide a business with higher productivity and employees with more flexibility (Kasemap, 2014).

Social networking can be used as a platform for the creation of virtual teams and provide them with a work environment. To this end, popular social networks such as Facebook or Linkedln can be used, or the organization's internal network. The use of different social platforms provides the members of an organization a chance for formal and informal communication. In this way, it enables both easier transfer of information and streamlined relationship building. It also often serves as a platform for team-building, through the different available application that enable members from diverse geographical areas to participate and provide input. They have proven to be especially useful in global businesses' organizational arrangements. For example, employees working from distance or who spend a lot of time out of the organization often find it difficult to stay a part of the organizational culture. This is why E-leaders use social networks to share the values of the organization and keep them informed about on-going changes and development. For this reason, it should be ensured that the external members remain part of organizational culture. Certain findings in the literature state that businesses that have implemented social networks in their organizations have also encountered a switch in organizational culture - from information gathering to information participation (Weeks et. al. 2017).

Leadership uses social networks as a tool for acquiring and utilizing social capital. Effective leaders enable complete interconnectedness, information and solution sharing, and, most importantly, support the open communication of team members. Moreover, leaders use social networks to combine different skills, knowledge and individuals' experiences within a team to generate new and innovative solutions and ideas by giving them a space for instant discussion and feedback. Additionally, social networks help flatten the hierarchies within a team and thus constitute a reflection of a participative leadership model (Avolio et. al., 2014). To sum up, social networks serve as a platform for collaboration, contribution and community creation.

However, using social networks as a tool of leadership does not always yield positive results. While a constant availability of both leaders and team members may be beneficial in terms of quick feedback or guidance, it is usually connected with negative impact on team members. That is, being constantly available requires team members to multitask, which contributes to burnout, stress, and a decline in productivity. In such situations, leaders are usually incentivized to change their leadership style in order to revive organizational balance (Kasemap, 2014).

\title{
8. Challenges in leading virtual teams
}

As new and different communication technologies, virtual teams also present a challenge for today's leaders. They necessitate new skills and styles that meet the needs of the team members. At this point, the relevance of combining the elements of the organizational culture(such as mutual mindset and vision) are chiefly in focus (Maynard et. al. 2017).

The first element that affects the style of leadership in virtual teams is the degree of virtually. This stretches from a very low level of virtually to virtual organizations depending on the frequency of digital communication, physical distance and percentage of time in virtual and in face-to-face surrounding. In terms 


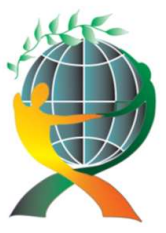

\author{
(online) $=$ ISSN $2285-3642$ \\ ISSN-L = $2285-3642$ \\ Journal of Economic Development, Environment and People \\ Volume 8, Issue 4, 2019
}

URL: http://jedep.spiruharet.ro

e-mail: office_jedep@spiruharet.ro

of the frequency of usage, it has been explained that it is proportionally related to the synchronization of technology flow. When it comes to physical distance and the frequency of digital communication, it is said that though team members may be positioned in the same location that does not necessarily imply that the virtuality level is low. On the contrary, it has been suggested that in organizations in which team leaders provide conditions for adequate ICT-mediated communication, the level of virtuality is also high. Thus, the challenge for virtual teams' leaders is to provide a smooth and uninterrupted use of technology such as videoconference calls without long pauses during the conversation (Alsharo et. al. 2017).

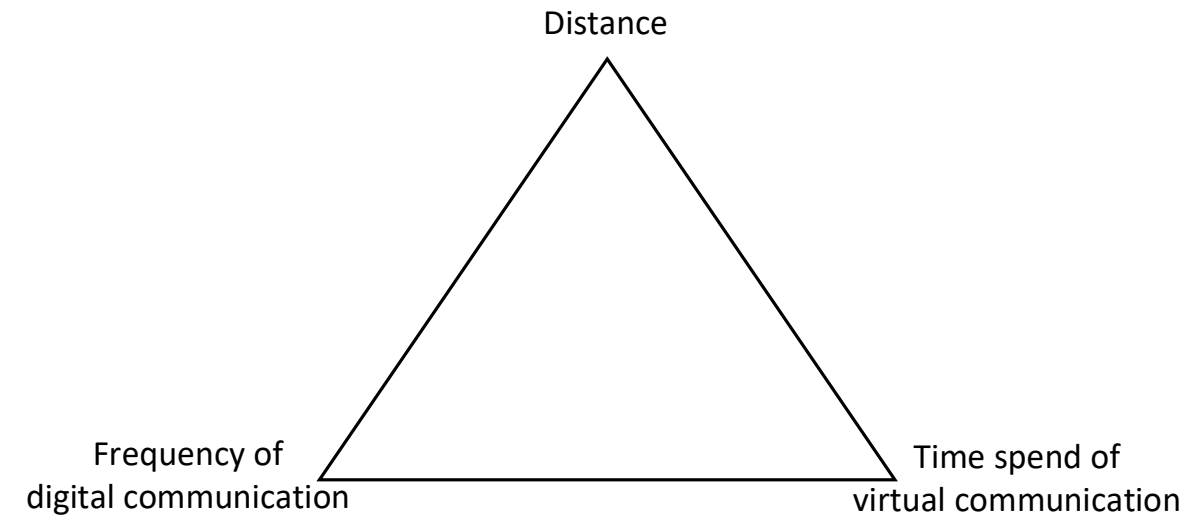

Fig. 2: Own representation based on Maynard, Gilson, Jones Young, \& Vartiainen (2017, p. 325)

Further challenge for e-leaders is strengthening communication between the team members and working on trust building. Communication and trust building can be observed as a combined unit, as one is conditioned by the other. Similar to as in traditional teams, virtual teams also need to have a defined objective and norms, measurable goals and easy access to information. To enable easy communication inside the team, it is suggested to form smaller groups with not more than 12 people per group, which would be able to exchange information and feedback more frequently (Kasemap, 2014). That way it would also create a base for higher sense of trust. According to Ford et. al. (2017) trust is built among the members via mutual communication and collaboration. Building trust is likely the most challenging task facing E-leaders, because it requires an alignment of both cognitive and affective elements. Trust has been referred to in a positive connection with performance as well as with team members' overall satisfaction (Chen et. al. 2010). In a recently published study by Croes et. al. (2019), it was found that non-verbal communication is severely impaired, especially in virtual teams, which makes collaboration even more difficult.

Collective awareness is the point at which cultural elements affect e-leadership the most. This may be the most difficult challenge of all those mentioned, because it requires that all of the participants undergo a shift in mindset (Walumbwa et. al., 2007). In this context, Van Wart et. al. (2017) describes how e-leaders need to develop a culture in order to adapt more effectively to these technical changes. The leader's task in this case is to create a mutual vision on a team level, which helps prevent misunderstanding and enables effective communication. The need for cultural awareness appeared because of the lack of information, reaction or feedback, which are not transmitted in virtual contexts as they are in face-to-face interactions (Chen et. al. 2010). This causes team members to build a certain level of mistrust and hesitate before 


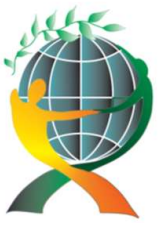

\author{
(online) $=$ ISSN $2285-3642$ \\ ISSN-L = $2285-3642$ \\ Journal of Economic Development, Environment and People \\ Volume 8, Issue 4, 2019 \\ URL: http://jedep.spiruharet.ro \\ e-mail: office jedep@spiruharet.ro
}

interacting. There are various consequences of mistrust, such as misinterpretation, a slower exchange of information or even a feeling of isolation from the group. An e-leader needs to provide all the information available, as well as decide on a framework of rules, norms and behaviors that are to be practiced by all members of the group. The framework enables team members to grow accustomed to their own activities and reactions, avoid misunderstanding and accelerate the process. It also helps eliminate the sense of uncertainty common in virtual environments (Daassi et. al., 2010).

Nonetheless, to overcome all these challenges, leaders of virtual teams need to start by changing themselves. A leader is a key factor for shaping organizational culture and cooperation. Leaders serve as a 'relationship mediators' and use their skills to create a positive organizational dynamic. They need to always consider how to enhance their effectiveness, as the studies in the literature show that the effectiveness of a team is highly dependent upon the performance of leaders (Chen et. al. 2010).

\title{
9. Limitations \& Further outlook
}

As digital elements have become more prevalent in companies in recent years, much research has been done to understand what impact they could have on corporate surface. Considering the importance and the degree of implementation of digitalized business models in the modern age, it is surprising that a significant majority of the findings in the literature are still based on the consequences by E-leadership instruments. In more recent literature, quite a few journal articles describe this topic and try to provide a framework connecting cultural elements regarding digital leadership instruments. Consequently, new topics and conceptual questions arise. Although the importance of creating a mutual vision and digital awareness is highlighted in most of the literature's findings, it does not include specific measures regarding leaders or employees.

In addition, the need to specify collaborative technologies in a virtual environment was addressed. In order to find out which is the most effective solution for the team and the leader, intensive collaboration is cited as a crucial factor. However, the results have shown that by offering a broader range of technologies to a team, the one known to the majority of the team members is most likely to be used. The conclusion from this statement is that the multiple features of the technology are equally important. Higher performance is expected as the knowledge of the specific technological features is expanded (Daassi et al. 2010). It is also important to clearly communicate the responsibilities and roles to each team member. It has been highlighted as an important factor for effective collaboration and certainly requires further attention. An empirical study that takes into account the exact roles and tasks would be useful. Finally, a case study of a company could be helpful to illustrate the practical experiences with the different e-media.

\section{Acknowledgements}

I thank the Kaposvar University for supporting me with provided statistical materials and Ms. Joana Jevic for assisting me in performing.

\section{References}

[1] Alsharo, M., Gregg, D., \& Ramirez, R. (2017). Virtual team effectiveness: The role of knowledge sharing and trust. Information \& Management, 54(4), 479-490. 


\author{
(online) $=$ ISSN $2285-3642$ \\ ISSN-L $=2285-3642$ \\ Journal of Economic Development, Environment and People \\ Volume 8, Issue 4, 2019 \\ URL: http://jedep.spiruharet.ro \\ e-mail: office_jedep@spiruharet.ro
}

[2] Avolio, B. J., Kahai, S., Dumdum, R., \& Sivasubramaniam, N. (2001). Virtual teams: Implications for e-leadership and team development.

[3] Avolio, B. J., \& Kahai, S. S. (2003). Adding the" E" to E-Leadership: How it may impact your leadership. Organizational Dynamics.

[4] Avolio, B. J., Sosik, J. J., Kahai, S. S., \& Baker, B. (2014). E-leadership: Re-examining transformations in leadership source and transmission. The Leadership Quarterly 25, 105-113.

[5] Bossink, B. Effectiveness of innovation leadership styles: a manager's influence on ecological innovation in construction project. Construction Innovation 2004; 4(1), 211-228.

[6] Braun, S., Hernandez Bark, A., Kirchner, A., Stegmann, S., \& Van Dick, R. (2019). Emails From the Boss-Curse or Blessing? Relations Between Communication Channels, Leader Evaluation, and Employees' Attitudes. International Journal of Business Communication, Vol. 56(1) $50-81$.

[7] Cascio, W. F., \& Shurygailo, S. (2003). E-leadership and virtual teams. Organizational dynamics.

[8] Chen, C. C., Harris, A. L., \& Wu, J. (2010). Enhancing Virtual Learning Team Performance: A Leadership Perspective. In P. Yoong, Leadership in the digital enterprise: issues and challenges (pp. 91-104). New York: IGI Global.

[9] Croes, E. A., Antheunis, M. L., Schouten, A. P., \& Krahmer, E. J. (2019). Social attraction in video-mediated communication: The role of nonverbal affiliative behavior. Journal of social and personal relationships, 36(4), 12101232.

[10] DasGupta, P. (2011). Literature Review: e-Leadership . Emerging Leadership Journeys, Vol. 4 Iss. 1, pp. 1- 36.

[11] Daassi, M., Jawadi, N., Favier, M., \& Kalika, M. (2010). Building Collective Awareness in Virtual Teams: The Effect of Leadership Behavioral Style. In P. Yoong, Leadership in the Digital Enterprise: Issues and Challenges (pp. 105-117). New York: IGI Global.

[12] Day, D. V., Fleenor, J. W., Atwater, L. E., Sturm, R. E., \& McKee, R. A. (2014). Advances in leader and leadership development: A review of 25 years of research and theory. The leadership quarterly, 25(1), 63-82.

[13] Denton, D. K. (2006). Using intranets to make virtual teams effective. Team Performance Management, Vol. 12, No. $7 / 8,253-257$.

[14] DuBrin, A. J. (2015). Leadership: Research Findings, Practice, and Skills. Boston: Cengage Learning. 233-268.

[15] Fan, K. T., Chen, Y. H., Wang, C. W., \& Chen, M. (2014). E-leadership effectiveness in virtual teams: Motivating language perspective. Industrial Management \& Data Systems, 114(3), 421-437.

[16] Ford, R. C., Piccolo, R. F., \& Ford, L. R. (2017). Strategies for building effective virtual teams: Trust is key. Business Horizons, 60(1), 25-34.

[17] Greenhalgh, T., Robert, G., Macfarlane, F., Bate, P., \& Kyriakidou, O. (2004). Diffusion of innovations in service organizations: systematic review and recommendations. The Milbank Quarterly, 82(4), 581-629.

[18] Hambley, L. A., O'Neill, T. A., \& Kline, T. J. (2007). Virtual team leadership: The effects of leadership style and communication medium on team interaction styles and outcomes. Organizational behavior and human decision processes, 103(1), 1-20.

[19] Hertel, G., Stone, D. L., Johnson, R. D., \& Passmore, J. (2017). The Willey Blackwell handbook of the psychology of the Internet at work. Willey Blackwell. 


\author{
(online) $=$ ISSN $2285-3642$ \\ ISSN-L $=2285-3642$ \\ Journal of Economic Development, Environment and People \\ Volume 8, Issue 4, 2019 \\ URL: http://jedep.spiruharet.ro \\ e-mail: office_jedep@s,spiruharet.ro
}

[20] Hoch, J. E., \& Kozlowski, S. W. (2014). Leading virtual teams: Hierarchical leadership, structural supports, and shared team leadership. Journal of applied psychology, 99(3), 390.

[21] Jiang, H., Luo, Y., \& Kulemeka, O. (2016). Leading in the digital age: A study of how social media are transforming the work of communication professionals. Telematics and Informatics, 33(2), 493-499.

[22] Kasemap, K. (2014). The Role of Social Networking in Global Business Environment. In P. A. Smith, \& T. Cockburn, Impact of Emerging Digital Technologies on Leadership in Global Businesses (pp. 183-201). Hershey: IGI Global.

[23] Klus, M. F., \& Müller, J. (2018). Identifying Leadership Skills Requires in the Digital Age. Münster: Institut für Organisationsökonomik.

[24] Liu, C, Ready, D., Roman, A., Van Wart, M., Wang, X., MacCarthy, A., \& Kim, S. (2018). E-leadership: an empirical study of organizational leaders' virtual communication adoption. Leadership \& Organization Development Journal, Vol. 39 Issue: 7, pp.826-843.

[25] Manole, I. (2014). Virtual Teams and E-Leadership in the Context of Competitive Environment - Literature Review. Journal of Economic Development, Environment and People, Volume 3, Issue 3, 2285 - 3642.

[26] Maynard, T. M., Gilson, L. L., Jones Young, N. C., \& Vartiainen, M. (2017). Virtual Teams. In G. Hertel, D. L. Stone, R. D. Johnson, \& J. Passmore, The Willey Blackwell handbook of the psychology of the Internet at work (pp. 315-346). Hoboken: Willey Blackwell .

[27] McCann, J., \& Sweet, M. (2014). The perceptions of ethical and sustainable leadership. Journal of Business Ethics, 121(3), 373-383.

[28] Mironescu, R. (2013). The Importance of Management and Leadership in a Changing Business Environment. Studies and Scientific Researches. Economics Edition.

[29] Mittelstand 4.0 Agentur Kommunikation. (2016). Mittelstand im digitalen Wandel: Bedarfs-und Trendanalyse zu Führungskultur und Veränderungsmangement. Retrieved from https://www.businessschoolberlin.de/fileadmin/Daten/BSP/Hochschule/Presse/News_2017/Studie_Bedarfsund_Trendanalyse_Veraenderungsmanagement.pdf (Access July 2019).

[30] Paley, N. (2017). Leadership Strategies in the Age of Big Data, Algorithms, and Analytics. Boca Raton, FL: CRC Press, Taylor \& Francis Group.

[31] Poell, T., Abdulla, R., Rieder, B., Woltering, R., \& Zack, L. (2016). Protest leadership in the age of social media. Information, Communication \& Society, 19(7), 994-1014.

[32] Roman, A. W., Van Wart, M., Wang, X., Liu, C., Kim, S., \& McCarthy, A. (2018). Defining E-Leadership as Competence in ICT-Mediated Communications: An Exploratory Assessment. Public Administration Review, Vol. 00, Iss. 00, pp. $1-14$.

[33] Schmidt, G. B. (2014). Virtual leadership: An important leadership context. Industrial and Organizational Psychology, 7(2), 182-187.

[34] Schoemaker, P. J., Heaton, S., \& Teece, D. (2018). Innovation, dynamic capabilities, and leadership. California Management Review, 61(1), 15-42.

[35] Sfantou, D., Laliotis, A., Patelarou, A., Sifaki-Pistolla, D., Matalliotakis, M., \& Patelarou, E. (2017). Importance of leadership style towards quality of care measures in healthcare settings: a systematic review. In Healthcare (Vol. 5, No. 4, p. 73). Multidisciplinary Digital Publishing Institute. 


\author{
(online) $=$ ISSN $2285-3642$ \\ ISSN-L $=2285-3642$ \\ Journal of Economic Development, Environment and People \\ Volume 8, Issue 4, 2019
}

URL: http://jedep.spiruharet.ro

e-mail: office_jedep@spiruharet.ro

[36] Smith, P. A., \& Cockburn, T. (2014). Reflecting Emerging Digital Technologies in Leadership Models. Hershey: Business Science Reference.

[37] Thomson, P., Johnson, M., \& Devlin, J. (2018). Conquering Digital Overload: Leadership Strategies that Build Engaging Work Cultures. Cham, Switzerland: Springer Nature.

[38] Van Wart, M., Roman, A., \& Pierce, S. (2016). The rise and effect of virtual modalities and functions on organizational leadership: tracing conceptual boundaries along the e-management and e-leadership continuum. Transylvanian Review of Administrative Sciences, 12(SI), 102-122.

[39] Van Wart, M., Roman, A., Wang, X., \& Liu, C. (2017). Integrating ICT adoption issues into (e-) leadership theory. Telematics and Informatics, 34(5), 527-537.

[40] Van Wart, M., Roman, A., Wang, X., \& Liu, C. (2019). Operationalizing the definition of e-leadership: identifying the elements of e-leadership. International Review of Administrative Sciences, 85(1), 80-97.

[41] Vought, W. X. (2017, August). E-leadership in Practice: The Components of Transformational Leadership in Virtual Business Environments. Retrieved from Fisher Digital Publications : thttps://fisherpub.sjfc.edu/education_etd/323

[42] Walumbwa, F. O., Lawler, J. J., \& Avolio, B. J. (2007). Leadership, individual differences, and work-related attitudes: A cross-culture investigation. Applied psychology, 56(2), 212-230.

[43] Walumbwa, F. O., Wang, P., Lawler, J. J., \& Shi, K. (2004). The role of collective efficacy in the relations between transformational leadership and work outcomes. Journal of Occupational and Organizational Psychology, 77(4), 515-530.

[44] Weeks, B. E., Ardèvol-Abreu, A., \& Gil de Zúñiga, H. (2017). Online influence? Social media use, opinion leadership, and political persuasion. International Journal of Public Opinion Research, 29(2), 214-239.

[45] Zaccaro, S. J., \& Bader, P. (2003). E-leadership and the challenges of leading e-teams: Minimizing the bad and maximizing the good. Organizational dynamics. 